\title{
TAYLOR TESZT MODELLEZÉSE A JOHNSON-COOK ANYAGMODELL ALKALMAZÁSÁVAL: A HŐMÉRSÉKLET HATÁSA
}

\section{COMPUTATIONAL SIMULATION OF THE TAYLOR IMPACT TEST USING THE JOHNSON-COOK CONSTITUTIVE MODEL: THE EFFECT OF TEMPERATURE}

\author{
Varga Péter, Gonda Viktor, Rácz Pál \\ Óbudai Egyetem, BGK-AGI, 1081 Budapest, Népszínház u. 8. Telefon / Fax: +31-1- \\ 6665402,varga.peter@bgk.uni-obuda.hu
}

\begin{abstract}
Taylor impact testing is a high strain rate testing method. Although it is easy to execute, the stress state, and the deformation distribution within the specimen is complex. We examined the deformation of the specimen by the finite element method, by using the Johnson-Cook material model. We analyzed the effect of temperature on the deformation of a copper specimen at three different impact velocities.
\end{abstract}

Keywords: Taylor impact test, Johnson-Cook material model, finite element method.

\section{Összefoglalás}

Az extrém nagy alakváltozási sebességű mechanikai anyagvizsgálat egyik legegyszerúbben végrehajtható módja a Taylor-teszt. Egyszerüsége ellenére igen komplex az alakváltozás lefolyása és eloszlása a próbatestben. A próbatest alakváltozását végeselemes módszerrel vizsgáltuk, ahol anyagmodellnek a Johnson-Cook modellt választottuk. Vizsgáltuk a hőmérséklet hatását egy réz próbatest deformációjára három különböző sebességü becsapódás esetén.

Kulcsszavak: Taylor-teszt, Johnson-Cook anyagmodell, végeselemes módszer.

\section{Bevezetés}

Fémes szerkezeti anyagok nagy sebességü és nagymértékủ dinamikus terhelése létrejöhet lövedékek becsapódása-kor, jármüvek ütközésekor, vagy nagy sebességü képlékeny alakításkor pl. robbantásos vagy elektrodinamikus alakításkor. Ilyenkor a képlékeny alak-változási sebesség mértéke $>10^{3} \mathrm{~s}^{-1}$ nagy-ságrendủ is lehet. Az anyag makro deformációját a tömeghatás, az alakítási keményedés, a sebesség-érzékenység, valamint a képlékeny alakváltozás miatt kialakuló hőmérséklet-emelkedéssel járó lágyulás határozza meg. Az ún. Taylor üt- közési vizsgálattal [1] egy hengeres alakú próbatestet egy falnak lövünk, a deformált geometriából becsülhető a dinamikus alakítási szilárdság. A próbatest alakváltozásának modellezéséhez olyan anyagmodellt választhatunk, amivel a nagy alakváltozási sebesség tartományban is jól írja le az anyagi viselkedést, pl. az Armstrong-Zerilli modellt [2] vagy a Johnson-Cook modellt [3].

Egy OFHC réz próbatest Taylor tesztjének végeselemes szimulációját hoztuk létre a Johnson-Cook anyagmodellt felhasználva három becsapódási sebesség esetén, melyek 
értékeinél már képlékeny alakváltozás is létrejön, de képlékeny tönkremenetel még nem. Vizsgáltuk a képlékeny alakváltozás hatására kialakuló felhevülés okozta lágyulás hatását a kialakuló deformációra.

\section{Modellezés}

A Taylor teszt végeselemes szimulációját az MSC Marcban hoztuk létre. A hengeres próbatest kiinduló átmérője 7,62 mm, a hossza $l_{0}=25,4 \mathrm{~mm}$. A tengelyszimmetriát kihasználva síkbeli modellt készítettünk egy sugárnyi szélességgel. A hálót az érintkezési vonal (felület) irányába finomítottuk. A próbatest becsapódási sebessége (v): 130 $\mathrm{m} / \mathrm{s} ; 144 \mathrm{~m} / \mathrm{s}$; vagy $190 \mathrm{~m} / \mathrm{s}$ volt. A falat merevnek és súrlódásmentesnek tekintettük.

A próbatest anyagára lineárisan rugalmas-képlékeny modellt használtunk. A rugalmassági paraméterek értékei: rugalmassági modulus: $110 \mathrm{GPa}$; Poisson-tényezö: 0,33 . A képlékeny anyagmodellre a Johnson-Cook modellt választottuk [1]:

$k_{f}=\left(A+B \varepsilon_{e q}^{n}\right)\left(1+C \cdot \ln \frac{\dot{\varepsilon}_{e q}}{\dot{\varepsilon}_{0}}\right)\left(1-\left(\frac{T-T_{r}}{T_{m}-T_{r}}\right)^{m}\right)$

Ahol $k_{f}$ az alakítási szilárdság, $\varepsilon_{e q}$ az egyenértékủ alakváltozás, az az egyęénértékü alakváltozási sebesség. Az anyagmodell paraméterei OFHC rézre vonatkozóan: $A=$ $90 \mathrm{MPa} ; \quad B=292 \mathrm{MPa}$; $n=0,31 ; C=0,025 ; m=1,09 ; \dot{\varepsilon}_{0}=11 / \mathrm{s}$; $T_{r}=300 \mathrm{~K}$ [1]. A modellből számított folyási görbék $300 \mathrm{~K}$ és $600 \mathrm{~K}$ hömérsékleten, valamint $1 \frac{1}{\mathrm{~s}} \mathrm{~s}$ és $10^{5} \mathrm{1} / \mathrm{s}$ alakváltozási sebesség értékekhez az

\section{1. ábrán láthatók.}

Az OFHC réz további felhasznált fizikai paraméterei: olvadáspont: $T_{m}=1356 \mathrm{~K}$; sürüség: $8960 \mathrm{~kg} / \mathrm{m}^{3}$; fajlagos hőkapacitás: $383 \mathrm{~J} \cdot \mathrm{kg}^{-1} \cdot \mathrm{K}^{-1}$; hővezetési tényező: 401 $\mathrm{W} \cdot \mathrm{m}^{-1} \cdot \mathrm{K}^{-1}$; hőtágulási tényezö: $16,6 \mathrm{ppm} / \mathrm{K}$.

A számítási modell csak mechanikai (M), vagy csatolt termo-mechanikai (TM) esetre futtattuk le, dinamikus tranziens (explicit) megoldóval, a single step Houbolt eljárást használva, a nagy alakváltozás op- ciót beállítva. Az időlépést a modál analízisből kivett 2. sajátfrekvencia értékét felhasználva határoztuk meg, majd ezt finomítottuk, $10^{-7} \mathrm{~s}$ körüli értéken.

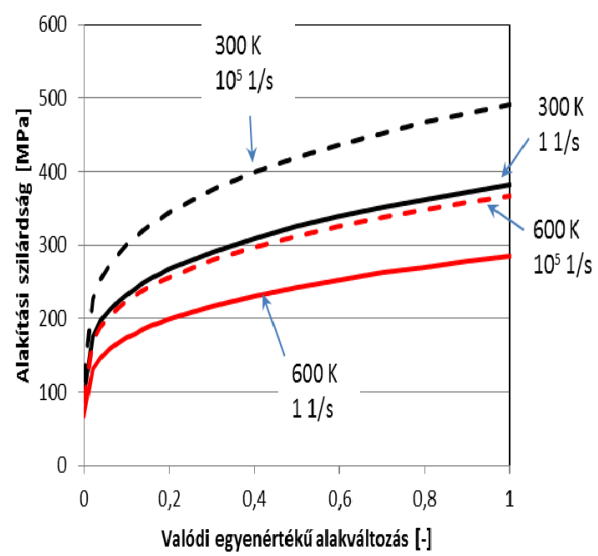

1. ábra. A réz folyási görbéi a Johnson-Cook modellböl számítva.

\section{Eredmények és következtetések}

Az alakváltozások eloszlása az ütköző felület közelében a 2. ábrán látható tisztán mechanikai modell esetére (a, c, e) ábra, valamint a képlékeny alakváltozás hatására kialakuló hömérséklet-növekedést figyelembe véve (b, d, f) ábra. Az alakváltozás eloszlásában nincs jelentős különbség az M és a TM modell között. Az M modellben végig $300 \mathrm{~K}$ a hőmérséklet, a TM modellben a létrejövő legnagyobb hőmérséklet a próbatestekben $458,7 \mathrm{~K}$; 492,9 K; illetve $639,7 \mathrm{~K}$ a $130 ; 144$; valamint $190 \mathrm{~m} / \mathrm{s}-\mathrm{os}$ becsapódási sebesség-ekhez. A legnagyobb alakváltozás értékeit összehasonlítva az M modellben 1,$3 ; 1,5$ és 2,3-as értékeket kapunk a, a TM modellnél a lágyulás miatt a növekedés csak $5 \%$ alatti.

A próbatest ütközés utáni és ütközés előtti hosszának arányait tekintve gyakorlatilag ugyanakkora arányokat kapunk $(0,81$; $0,78$; és 0,67$)$ a növekvö becsapódási sebességekhez mindkét modellnél. 
Mechanikai modell



a)

$\mathrm{v}=130 \mathrm{~m} / \mathrm{s}$

$\mathrm{l}_{1}=0,812 \mathrm{l}_{0}$

$\varepsilon_{\text {eq max }}=1,301$

c)

$\mathrm{v}=144 \mathrm{~m} / \mathrm{s}$

$1_{1}=0,7821_{0}$

$\varepsilon_{\text {eq } \max }=1,5$
Termikus és mechanikai modell



b)

$\mathrm{v}=130 \mathrm{~m} / \mathrm{s}$

$1_{1}=0,8111_{0}$

$\varepsilon_{\text {eq } \max }=1,349$

$\mathrm{T}_{\max }=458,7 \mathrm{~K}$

d)

$\mathrm{v}=144 \mathrm{~m} / \mathrm{s}$

$1_{1}=0,781_{0}$

$\varepsilon_{\text {eq } \max }=1,568$

$\mathrm{T}_{\max }=492,9 \mathrm{~K}$
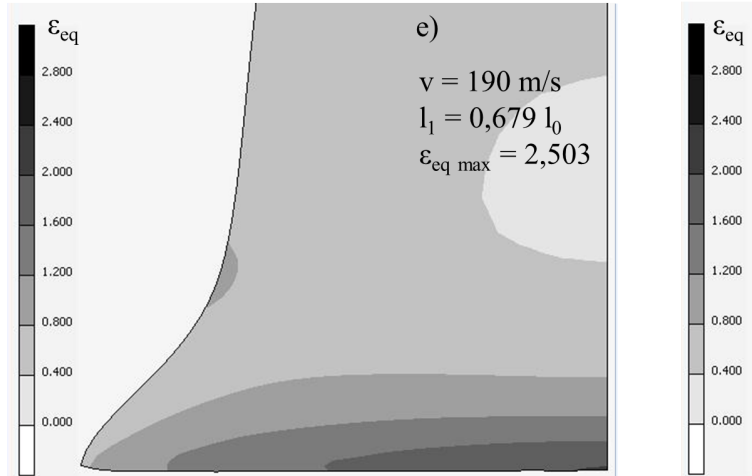

f)

$\mathrm{v}=190 \mathrm{~m} / \mathrm{s}$

$\mathrm{l}_{1}=0,676 \mathrm{l}_{0}$

$\varepsilon_{\text {eq } \max }=2,684$

$\mathrm{T}_{\max }=639,7 \mathrm{~K}$

2. ábra. Az alakváltozások számitott eloszlása a mechanikai és a csatolt termikus mechanikai modellnél 130, 144 és $190 \mathrm{~m} / \mathrm{s}$ becsapódási sebességnél az ütközö felület közelében. 


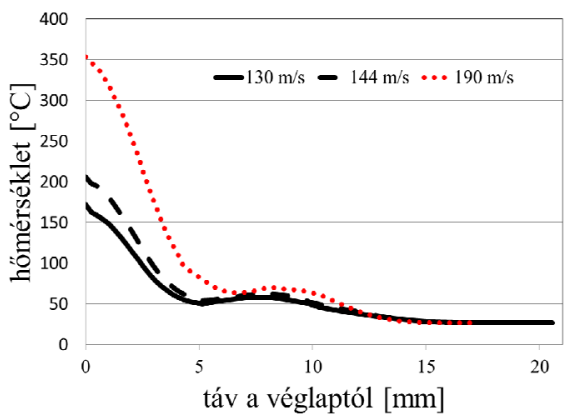

3. ábra. A szimmetriatengelyen számitott hömérséklet 130, 144, és $190 \mathrm{~m} / \mathrm{s}$ becsapódási sebességekhez.

Ezek az arányok megegyeznek az irodalomban található értékekkel [1].

A hőmérséklet eloszlásokat a szimmetriatengelyen vizsgálva a maximális alakváltozás elérésekor (3. ábra) látható, hogy a nagy hőmérsékletnövekedés az ütköző felülethez közeli (kb. 5 mm-es) tartományban alakul ki. A két modellt összevetve a legnagyobb becsapódási sebességnél (4. ábra), az alakváltozások szimmetriatengelyen vett eloszlását összehasonlítva csekély különbség látható a becsapódási felület 5 mm-es közelében. Három deformációs tartomány különböz-tethető meg: a becsapódáshoz közeli (0-5 $\mathrm{mm})$ nagy alakváltozási rész $\left(\varepsilon_{e q}>0,5\right)$, kis képlékeny alakváltozó rész $\left(\varepsilon_{e q}<0,5\right)(5-13 \mathrm{~mm})$, valamint a maradó alakváltozást nem szenvedő rész (13 mm felett), itt csak rugalmas alakváltozások jönnek létre. A próbatest két felületén ébredő axiális feszültségek időbeli lefolyását az 5. ábrán láthatjuk. A nagy, képlékeny alakváltozást okozó nyomófeszültség lecsengése után komplex módusú rugalmas lengés alakul ki a próbatestben.

A lokalizált nagy alakváltozású zónában létrejövő kb. $300 \mathrm{~K}$ hőmérsékletnövekedés az alakítási szilárdságot nem csökkenti olyan mértékben, hogy nagymértékben nőnének az alakváltozások, ezért a próbatest teljes hosszában sem lesz jelentős a rövidü- lés a hőmérséklet hatását figyelembe véve a vizsgált becsapódási sebességeknél.

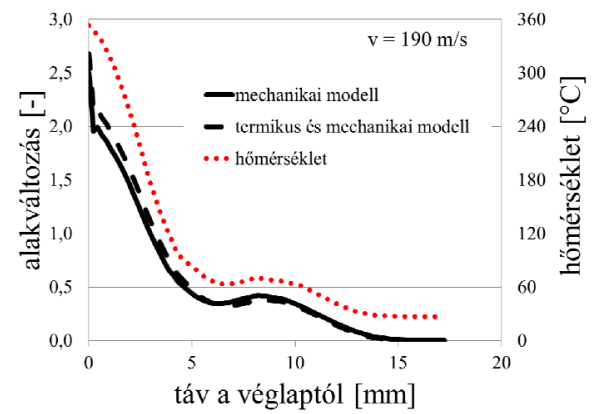

4. ábra. A szimmetriatengelyen számitott alakváltozások a mechanikai és csatolt termikus és mechanikai modellre, $190 \mathrm{~m} / \mathrm{s}$ becsapódási sebességnél. A csatolt modell hömérsékletei a szimmetria-tengelyen.

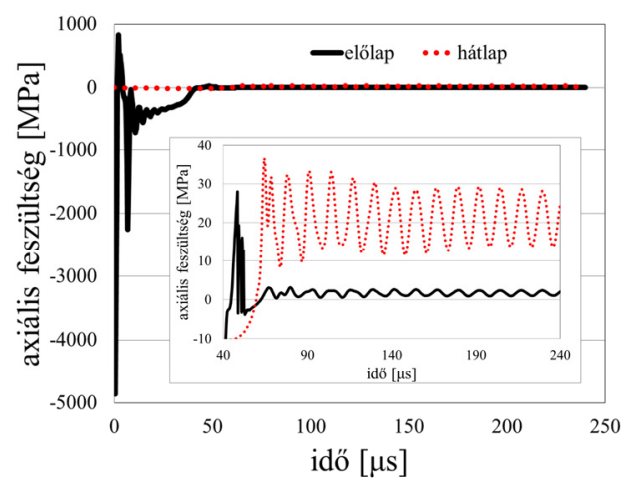

5. ábra. A szimmetriatengely két végén számitott axiális feszültségek az idö függvényé-ben. Az inzert a rugalmas lengéseket mutatja.

\section{Szakirodalmi hivatkozások}

[1] Taylor, G. I.: The testing of materials at high rates of loading, J. Inst. Civil Eng. 26, 1946. 486-519.

[2] Forde, L. C., Proud, W. G., Walley, S. M.: Symmetrical Taylor impact studies of copper, Proc. R. Soc. A 465, 2009. 769-790.

[3] Johnson, G.R., Cook, W.H.: A constitutive model and data for metals..., Proc. 7th Int. symp. on Ballistics, The Netherlands, 1983. 541-547. 